\title{
RANCANG BANGUN ALAT UKUR KEKENTALAN OLI SAE 10-30 MENGGUNAKAN METODE FALLING BALL VISCOMETER (FBV) SMALL TUBE
}

\author{
Asi Noflanda Arsis ${ }^{1}$, Dahyunir Dahlan' ${ }^{1}$, Harmadi ${ }^{1}$ \\ Muharmen Suari ${ }^{2}$ \\ ${ }^{1}$ Program Pascasarjana FMIPA Universitas Andalas \\ ${ }^{2}$ UPT Laboratorium Dasar dan Sentral Universitas Andalas, Limau Manis, Padang \\ 25163 \\ e-mail: harmadi@fmipa.unand.ac.id \\ adx_achye_arsis@yahoo.com
}

\begin{abstract}
ABSTRAK
Alat ukur kekentalan oli SAE 10-30 telah dirancang bangun dengan menggunakan metode Falling Ball Viscometer (FBV) small tube. Tabung yang digunakan berukuran kecil dengan panjang $15 \mathrm{~cm}$ dan diameter 5,5 mm. Alat ukur dilengkapi dengan dua sistem sensor yaitu Light Emitting Diode (LED) infra merah dan fotodioda. Data waktu tempuh bola magnetik yang direkam oleh sistem sensor diproses oleh mikrokontroler Arduino nano untuk kemudian ditampilkan dalam bentuk nilai kekentalan pada layar Liquid Crystal Display (LCD). Temperatur pengukuran divariasikan dari 30 ${ }^{\circ} \mathrm{C}$ sampai $100{ }^{\circ} \mathrm{C}$. Nilai regresi yang di peroleh saat temperatur dinaikkan yaitu 0,991 . Nilai Regresi pada saat temperature diturunkan yaitu 0,977. Nilai regresi yang didapatkan menunjukkan bahwa alat yang telah dirancang bekerja dengan baik dan dapat digunakan untuk menentukan nilai kekentalan oli SAE 10-30.

Kata kunci: Falling Ball Viscometer (FBV), Arduino Nano, Kekentalan, Oli SAE 10-30, Temperatur.
\end{abstract}

\begin{abstract}
The SAE 10-30 oil viscosity meter using falling ball viscometer (FBV) small tube method has been designed and developed. The viscosity meter uses small tube of $15 \mathrm{~cm}$ length and of $5.5 \mathrm{~mm}$ diameter. The viscosity meter is equipped with two sensors that are an infrared Light Emitting Diode (LED) and a photodiode. Travel time of a small magnetic ball measured by the sensors is processed by an Arduino nano microcontroller system and then displayed on Liquid Crystal Display (LCD) screen in term of oil viscosity. Effect of temperature on oil viscosity was investigated by varying oil temeperature between $30^{\circ} \mathrm{C}$ and $100^{\circ} \mathrm{C}$. The regression obtained when the temperature was increased was 0.991 . The score of regression during lower temperatures was 0.997. The regression values obtained showed that the tool that has been designed worked well and could be used to determine the value of oil viscosity SAE 10-30.
\end{abstract}

Keywords: Falling Ball Viscometer (FBV), Arduino Nano, viscosity, SAE 10-30 oil, Temperature. 


\section{PENDAHULUAN}

Pengukuran kekentalan zat cair yang umum dan paling sederhana adalah dengan menggunakan konsep hukum Stokes. Pengukuran kekentalan zat cair dengan hukum Stokes disebut dengan Falling Ball Viscometer (FBV) menggunakan konsep perhitungan waktu yang dibutuhkan suatu bola dengan diameter tertentu dan melewati sampel zat cair yang akan diukur kekentalannya pada jarak tertentu. Eksperimen menentukan kekentalan zat cair dengan konsep FBV masih menggunakan cara manual, perhitungan waktu masih mengandalkan penglihatan manusia dan stopwatch, human error masih menjadi permasalahan pada keakuratan hasil eksperimen, penentuan waktu awal bola memasuki tabung sampel dan waktu akhir bola mencapai dasar tabung.

Tissos (2014) membuat alat dengan sistem pengukuran kekentalan zat cair secara digital menggunakan sensor Efek Hall UGN3503 Berbasis mikrokontroler arduino uno 328, karena ukuran alat yang besar sehingga tidak praktis untuk digunakan. Penelitian yang dilakukan Wan Jong Kim dkk. (2016) dari Universitas Hansung di Korea Selatan membuat sebuah alat dalam bidang kesehatan yaitu untuk mengukur kekentalan darah, alat ini merupakan alat genggam yang mudah digunakan dan praktis, kelemahan dari penelitian ini hanya dapat digunakan untuk mengukur kekentalan darah dan tabung yang digunakan sulit untuk dibersihkan.

Berdasarkan permasalahan tersebut maka dilakukan penelitian rancang bangun alat ukur kekentalan oli menggunakan metode FBV dengan tabung berukukuran kecil, panjang 15 $\mathrm{cm}$ dan diameter $5,5 \mathrm{~mm}$. Alat ukur ini praktis untuk mengukur nilai kekentalan oli SAE 10-30 yang digunakan pada kendaraan bermotor.

Kekentalan adalah ukuran yang menyatakan besar kecil nya gesekan didalam fluida. Kekentalan merupakan sifat cairan yang berhubungan erat dengan hambatan untuk mengalir. Beberapa cairan ada yang dapat mengalir cepat, sedangkan lainnya mengalir secara lambat. Cairan yang mengalir cepat mempunyai kekentalan kecil, sedangkan cairan yang mengalir lambat mempunyai kekentalan besar (Estien, 2005).

Hambatan gerakan benda di dalam fluida disebabkan oleh gaya gesekan antara bagian fluida yang melekat ke permukaan benda dengan bagian fluida disebelahnya di mana gaya gesekan sebanding dengan koefisien kekentalan $\eta$ fluida. Menurut Stokes, gaya gesekan itu diberikan oleh apa yang disebut rumus Stokes

$$
F=\pi r \eta v
$$

dengan $F$ Gaya gesekan, $r$ jari-jari bola, $\eta$ koefisien kekentalan dan $v$ kecepatan jatuh bola. Pada dasarnya penentuan $\eta$ dengan menggunakan rumus Stokes sangatlah sederhana. Dengan menggunakan metode bola jatuh, maka sewaktu bola dijatuhkan ke dalam bejana yang berisi cairan atau fluida yang hendak ditentukan koefisiennya kekentalannya, oleh gaya beratnya, bola akan semakin cepat jatuhnya. Tetapi sesuai dengan rumus Stokes, makin cepat gerakannya, makin besar gaya gesekannya sehingga akhirnya gaya berat itu tepat seimbang dengan gaya gesekan dan jatuhnya bola dengan kecepatan tetap sebesar $v$ sehingga berlaku persamaan 


$$
m g=6 \pi r \eta v
$$

Dimana $m g$ merupakan gaya berat bola. Dengan memperhitungkan gaya ke atas Archimedes yang juga bekerja pada bola, maka akan dihasilkan persamaan:

$$
\eta=\frac{2}{q} r^{2} \frac{\rho-p 1}{w} g
$$

Rumus di atas hanya berlaku, asalkan besarnya kecepatan tidak sampai menimbulkan turbulensi. Bila ini terjadi, maka gaya penahan atau gaya gesekan fluida jauh lebih besar dari pada yang dihitung menurut hukum Stokes. Bila setelah $t$ detik bola telah mencapai kecepatan terminal $v$ dan telah menempuh jarak sebesar $d$ maka persamaan dapat ditulis sebagai:

$$
\eta=\frac{2 t r^{2} g}{9 d}\left(\rho_{b}-\rho_{f}\right)
$$

dengan $d$ jarak tempuh bola $(\mathrm{m}), t$ waktu tempuh bola (s), $r$ jari-jari bola $(\mathrm{m}), g$ percepatan gravitasi $\left(\mathrm{m} / \mathrm{s}^{2}\right), \eta$ koefisien kekentalan $(\mathrm{Pa} \mathrm{s}), \rho_{b}$ massa jenis bola $\left(\mathrm{Kg} / \mathrm{m}^{3}\right), \rho_{f}=$ massa jenis fluida $\left(\mathrm{Kg} / \mathrm{m}^{3}\right)$.

Berdasarkan persamaan di atas, dengan mengukur jari-jari bola, kecepatan jatuh $v$ sewaktu kecepatan itu tetap, dan diketahuinya $\rho_{\mathrm{b}}, \rho_{\mathrm{f}} \operatorname{dan} g$, dapatlah dihitung koefisien

kekentalan cairan $\eta$ di dalam bejana tersebut (Soedojo, 2004). Gaya-gaya yang bekerja pada saat bola berada dalam kecepatan tetap dapat dilihat pada Gambar 1

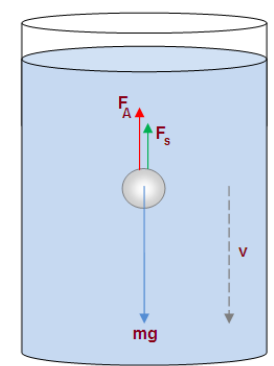

Gambar 1. Gaya yang Bekerja Pada Saat Bola Dengan Kecepatan Tetap

$F_{s}$ merupakan gaya Stokes dengan $F_{\alpha}$ gaya ke atas, dan $m g$ sebagai gaya berat. Satuan kekentalan fluida dalam sistem cgs adalah dyne det $\mathrm{cm}^{-2}$, yang biasa disebut dengan istilah poise, dimana 1 poise sama dengan 1 dyne det $\mathrm{cm}^{-2}$. Kekentalan dipengaruhi oleh perubahan temperatur. Apabila temperatur naik maka kekentalan menjadi turun atau sebaliknya (Soedojo, 2004)

Arduino Nano adalah salah satu varian dari produk board mikrokontroller keluaran Arduino dengan board Arduino terkecil, menggunakan mikrokontroller Atmega 328 untuk Arduino Nano 3.x dan Atmega168 untuk Arduino Nano 2.x. Arduino Nano tidak 
dilengkapi dengan soket catudaya, tetapi terdapat pin untuk catu daya luar atau dapat menggunakan catu daya dari mini USB port.

LED atau dioda pemancar cahaya adalah dioda semikonduktor yang dapat memancarkan cahaya jika diberi dibias maju.LED banyak dibuat dengan berbagai macam panjang gelombang sehingga dapat memancarkan warna cahaya yang berbeda-beda.LED yang memancarkan cahaya merah mempunyai panjang gelombang $\sim 650 \mathrm{~nm}$.

Fotodioda dibuat dari semikonduktor dengan bahan yang populer adalah silicon ( $\mathrm{Si}$ ) atau galium arsenida (GaAs), dan yang lain meliputi InSb, InAs, PbSe.Fotodioda digunakan sebagai penangkap gelombang cahaya yang dipancarkan oleh Inframerah.Besarnya tegangan atau arus listrik yang dihasilkan oleh Fotodioda tergantung besar kecilnya radiasi yang dipancarkan oleh inframerah (Fraden, 1996).

Prinsip kerja LM35 adalah sensor temperatur difungsikan untuk mengubah besaran temperatur menjadi tegangan, panas yang terdeteksi oleh LM35 sebagai sensor temperatur akan diubah menjadi tegangan. Sedangkan proses berubahnya panas menjadi tegangan dikarenakan di dalam LM35 ini terdapat termistor berjenis PTC (Positive Temperature Coefisient), yang mana termistor inilah yang menangkap adanya perubahan panas.

LCD merupakan perangkat yang digunakan untuk menampilkan data selain menggunakan seven segment. LCD adalah sebuah modul yang terdapat beberapa komponen yang disusun menjadi satu juga terdapat mikrokontroler didalamnya sebagai pengendali (Sulhan, 2006). LCD digunakan sebagai alat komunikasi antara user dengan peralatan yang dikontrol.

\section{METODE PENELITIAN}

Rancang bangun alat ukur kekentalan oli SAE10-30 menggunakan metode FBV small tube dilakukan di Laboratorium Elektronika dan Instrumentasi Jurusan Fisika FMIPA Universitas Andalas. Perancangan alat ukur terdiri dari perangkat keras dan perangkat lunak.

\subsection{Perancangan Perangkat Keras}

Alat ukur kekentalan Oli digital ini menggunakan sensor LED infra merah yang dipasangkan dengan fotodioda, sebagai sumber tegangan sistem ini memanfaatkan baterai 9 Volt. Secara umum rancang bangun alat dapat dilihat pada Gambar 2 


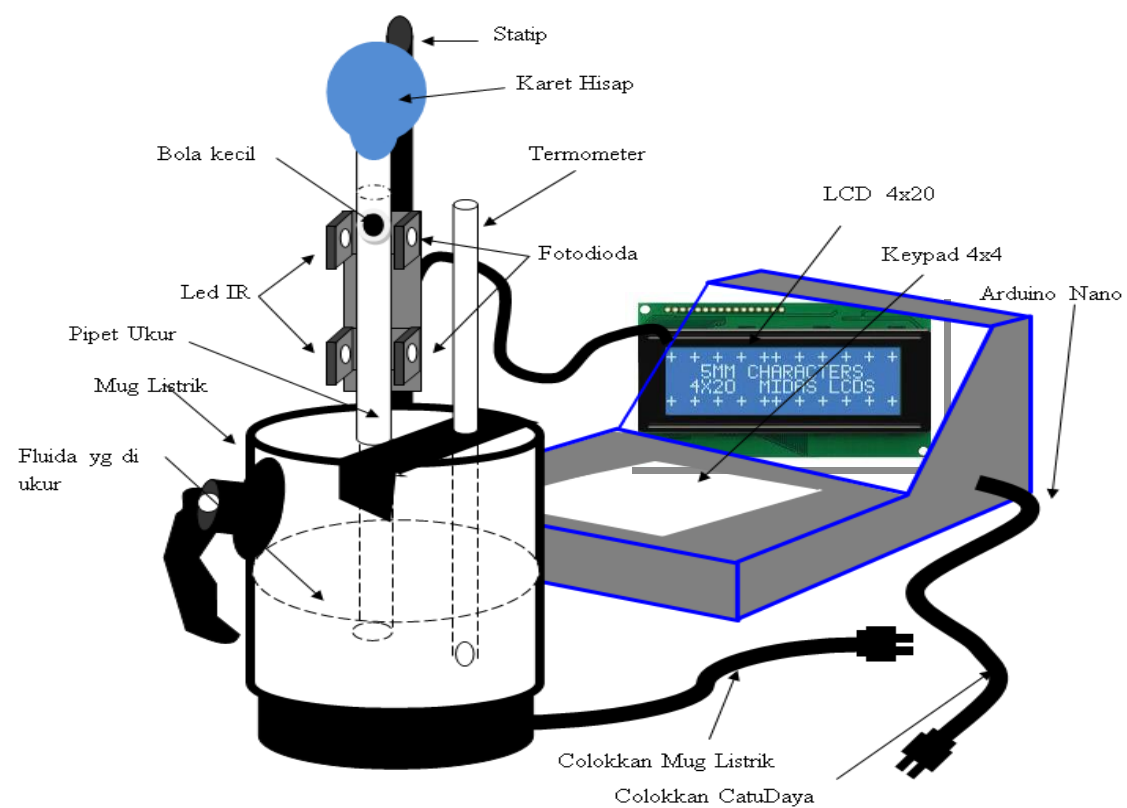

Gambar 2. Desain Sistem Pengukuran Kekentalan

Gambar 2 memperlihatkan rancang bangun sistem pengukuran kekentalan secara keseluruhan. Rancang bangun secara umum terbagi atas dua bagian, bagian detektor dan bagian rangkaian. Kekentalan oli diukur dengan menggunakan metode FBVsmall tube. LED memancarkan cahaya yang ditangkap oleh fotodioda, LED dan fotodioda diletakkan terpisah dan sejajar, diantara LED dan fotodioda diletakkan tabung yang berisi oli, bola magnet dijatuhkan dari atas tabung, ketika bola magnet melewati sensor pertama maka akan dideteksi oleh sensor sebagai waktu mulai, saat bola magnet sampai pada sensor kedua maka tercatat sebagai waktu berakhir, kemudian akan diolah oleh arduino nano dan nilai kekentalan akan ditampilkan pada LCD.

\subsection{Perancangan Perangkat Lunak}

Menjalankan suatu sistem instrumentasi berbasis mikrokontroler diperlukan urutan instruksi yang disebut program. Sistem alat ukur kekentalan ini ditulis dalam bahasa C. Rancang bangun perangkat lunak dari alat ukur kekentalan oli dimulai dari diagram alir. Desain perangkat lunak sesuai dengan prinsip kerja sistem yang dibangun. Berdasarkan prinsip kerja sistem yang direncanakan maka diagram alir program dapat ditampilkan seperti pada Gambar 3. Gambar 3 ini mengambarkan diagram alir dengan desain perangkat lunak dari sistem pengukuran kekentalan oli dengan menggunakan metode FBV small tube. Langkah diagram alir program dapat dijelaskan sebagai berikut. Mulamula program membaca konstanta yang telah ditanamkan kedalam program meliputi 
massa bola, jari jari bola, jarak antar dua sistem sensor cahaya, dan percepatan gravitasi. Setelah itu kita masukan massa dan volume dari oli yang digunakan dengan mengunakan keypad. Selanjutnya kita jatuhkan bola magnet. Saat bola melewati sensor pertama maka program akan mulai menghidupkan timer dan mencatat waktunya. Saat bola melewati sensor kedua maka timer dinon aktifkan dan program akan menampilkan waktu lama bola melewati dua sensor tersebut. Selanjutnya program akan menampilkan nilai dari kekentalan oli tersebut. Nilai kekentalan didapatkan dari perhitungan rumus kekentalan dengan menggunakan persamaan Stokes (Persamaan 1.4). Selain itu program juga menampilkan temperatur dari oli tersebut.Penentuan nilai kekentalan sudah selesai. Jika kita ingin mengulangi pembacaan kekentalan untuk jenis oli yang sama maka kita naikkan bola magnet dengan bantuan magnet keatas dan dijatuhkan kembali, program akan mengulangi langkah diatas. Namun jika ingin mengganti dengan oli yang lain maka kita inputkan massa jenis dari oli yang baru tersebut dan di ulangi langkah menjatuhkan bola magnet itu kembali. Pengukuran menggunakan temperatur yang berbeda maka panaskan oli dalam mug listrik dan diulangi langkah diatas. 


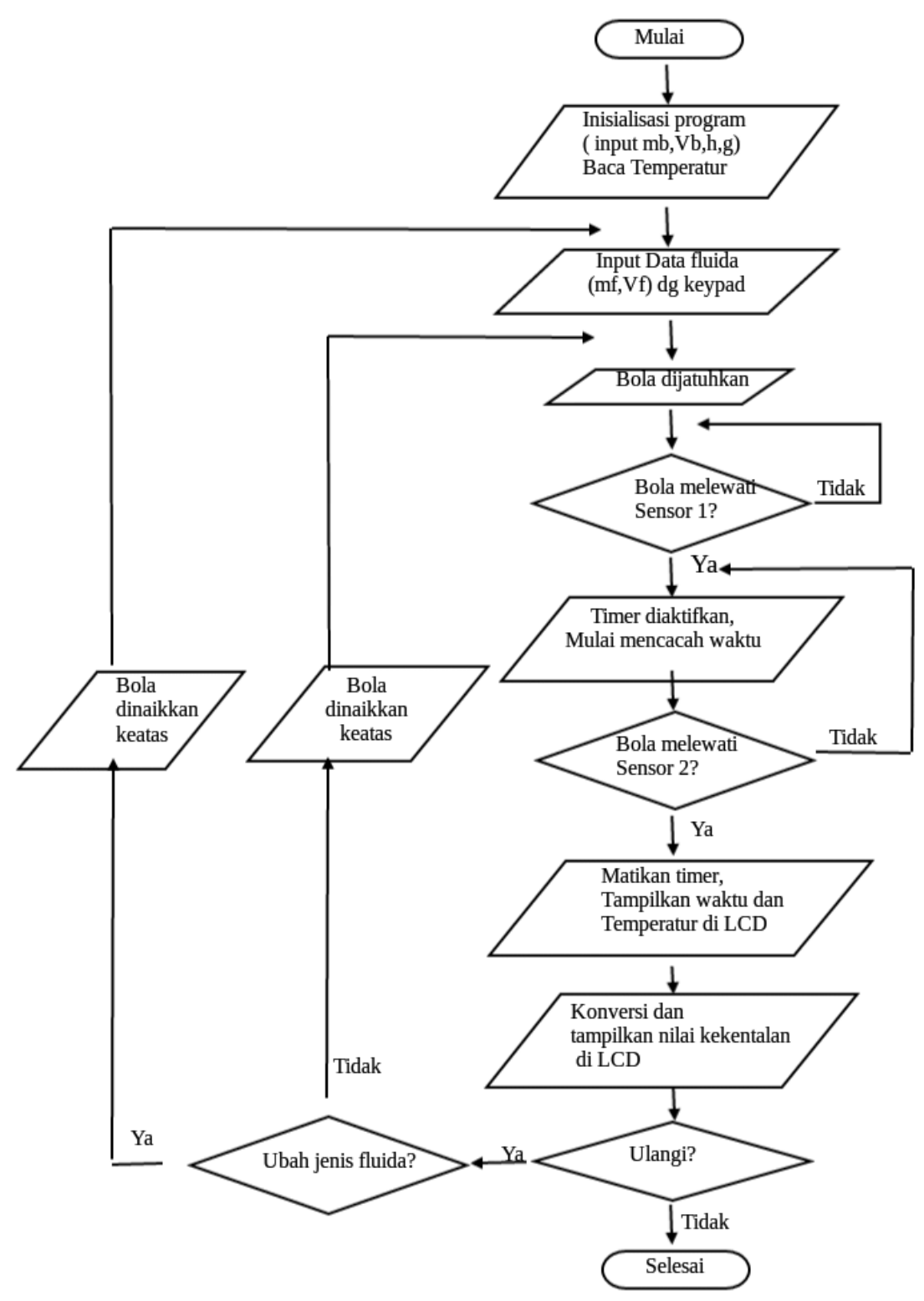

Gambar 3. Diagram Alir perangkat lunak rancang bangun alat ukur kekentalan oli 


\section{HASIL DAN DISKUSI}

\subsection{Rancang Bangun Alat ukur Kekentalan Oli}

Alat ukur kekentalan oli SAE 10-30 dengan menggunakan metode FBV small tube dapat dilihat pada Gambar 3.1memperlihatkan rancang bangun sistem pengukuran kekentalan secara keseluruhan. Alat ukur kekentalan oli ini bekerja pada saat alat terhubung dengan sumber tegangan, sistem yang bekerja pertama kali adalah bagian rangkaian arduino yang terhubung ke LCD. Saat ditekan tombol mulai maka sistem akan hidup secara keseluruhan. Setelah itu masukkan parameter dari persamaan (1.4). Sistem pengukuran viskositas berbasis digital ini dilengkapi dengan sistem input dan sistem output. Sistem input terdiri dari dua tombol yang mempunyai masing-masing fungsi yaitu tombol power On/Offyang berfungsi untuk menghidupkan dan mematikan sistem, tombol RESETyang berfungsi untuk mengembalikan mikrokontroler ke setting awal agar pengukuran selanjutnya bisa dilakukan. Sedangkan sistem output terdiri dari display LCD yang berfungsi untuk menampilkan temperatur, waktu tempuh bola magnet dan nilai kekentalan dari sampel yang diukur.

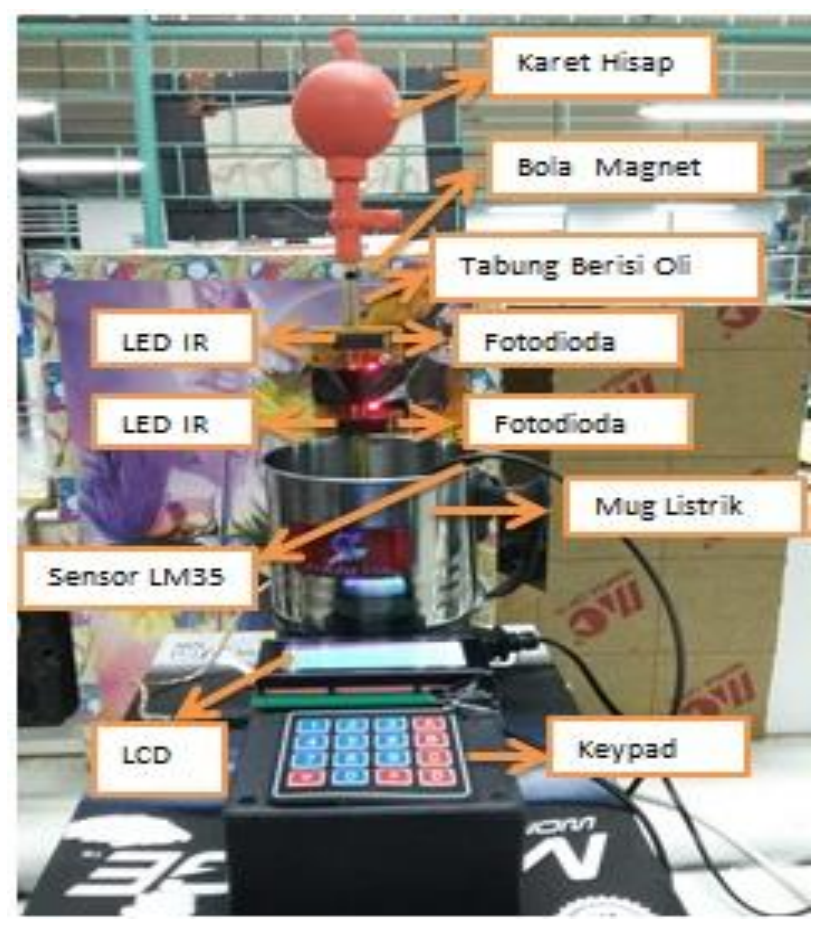

Gambar 4. Rancang bangun alat ukur kekentalan oli secara keseluruhan 


\subsection{Hasil Pengujian Rancang Bangun Alat Ukur Kekentalan Oli SAE 10-30 Menggunakan Metode FBV)Small Tube.}

Hasil mengujian ini akan memperlihatkan seberapa besar ketepatan alat ukur kekentalan oli yang telah dibuat. Prinsip kerja dari alat ukur kekentalan oli yaitu mendeteksi bola magnet yang dijatuhkan dalam sebuah tabung yang berisi oli SAE 10-30. Kekentalan oli akan diukur menggunakan metode FBV small tube. Hasil dari pengujian alat ukur kekentalan oli SAE 10-30 ketika temperatur naik dapat dilihat pada Gambar 5 yang dibandingkan dengan data acuan.

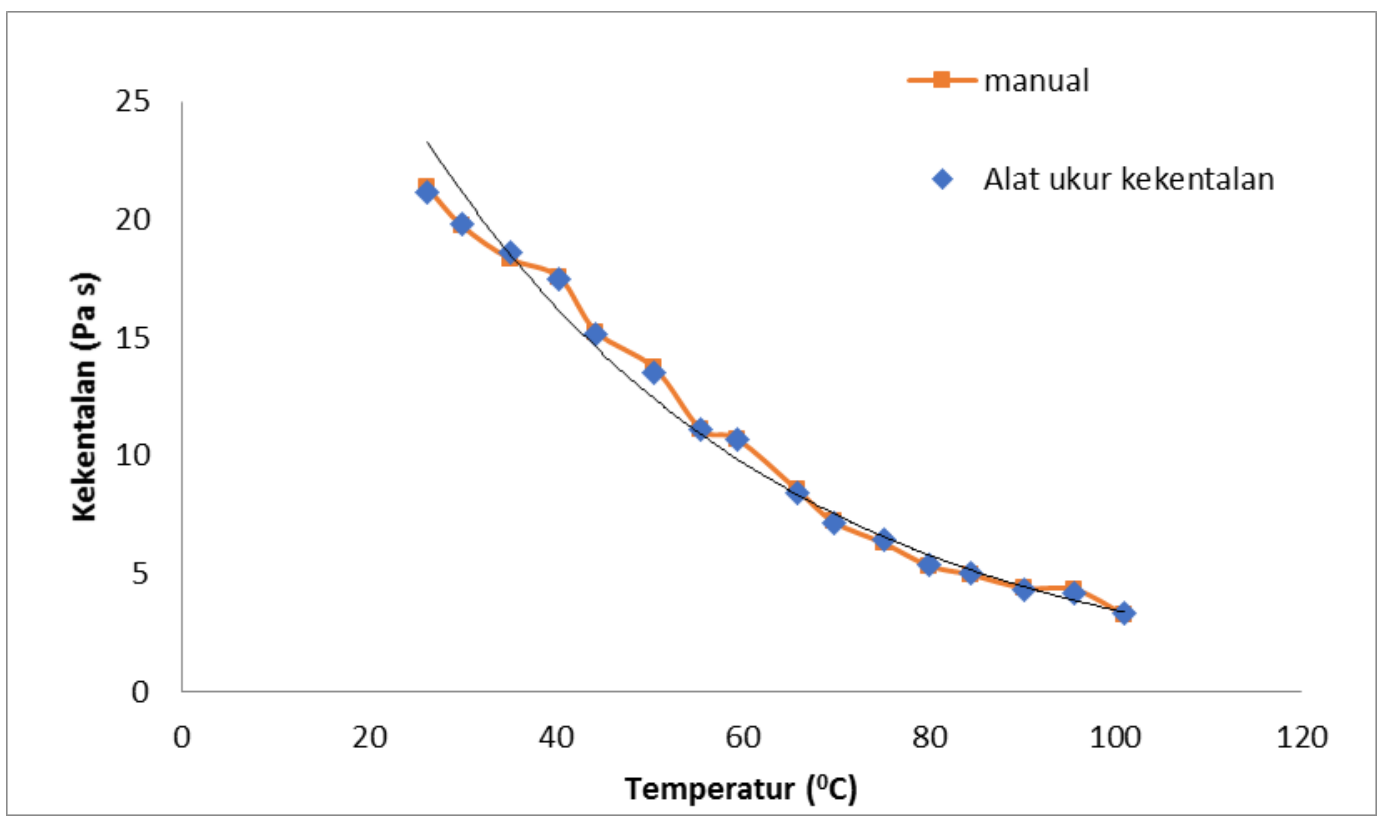

Gambar 5. Perbandingan data hasil pengujian alat ukur menggunakan metode FBV small tube dengan data acuan saat temperatur naik

Pada pengujian ini yang menjadi data acuan adalah nilai kekentalan oli SAE 10-30 yang didapatkan dengan menghitung waktu dari sensor pertama kesensor kedua menggunakan stopwatch, dengan nilai regresi yang didapatkan adalah 0,988 pada saat temperatur naik yang berarti nilai keabsahan dari fungsi grafik tinggi. Data hasil pengukuran oli menggunakan alat ukur memiliki nilai regresi 0,991 yang berarti nilai regresi ini mendekati nilai regresi data acuan bahkan lebih besar. Hal ini disebabkan karena data acuan didapatkan secara manual dengan cara menggunakan stopwatch untuk mengukur waktu bola jatuh dari sensor pertama ke sensor kedua. Peluang terjadinya kesalahan oleh manusia ketika menggunakan stopwacth (human error), misalnya bola telah mencapai sensor kedua, namun stopwatch terlambat untuk dihentikan atau terlalu cepat dihentikan. Berbeda dengan alat ukur yang dirancang, data waktu ketika bola jatuh dari sensor pertama ke sensor kedua dihitung secara digital. Bola akan terdeteksi secara otomatis 
ketika mencapai sensor kedua, sehingga program timer yang telah ditanam dalam arduino akan memproses selang waktu yang berlangsung dengan seketika. Perbandingan data acuan dengan data yang diukur oleh alat rancang dapat dilihat juga dengan menghitung besar error yang terjadi. Dari hasil perhitungan error didapatkan kesalahan rata-rata sebesar $1,17 \%$. Besar nilai kesalahan rata-rata ini cukup kecil.

Gambar 6 memperlihatkan perbandingan data hasil pengujian alat ukur menggunakan metode FBV small tube dengan data acuan saat temperatur turun didapatkan nilai regresinya 0,973 yang berarti nilai keabsahan dari fungsi grafik tinggi. Data hasil pengukuran oli menggunakan alat ukur ketika temperatur turun memiliki nilai regresi 0,977 yang berarti nilai regresi ini mendekati nilai regresi data acuan bahkan lebih besar. Hal ini disebabkan sama seperti yang terjadi saat temperatur naik yaitu penggunaan stopwatch dalam perhitungan waktu. Perbandingan data acuan dengan data yang diukur oleh alat rancang bangun alat ukur kekentalan oli SAE 10-30 menggunakan metode FBV small tube dapat dilihat juga dengan menghitung besar error yang terjadi. Hasil perhitungan error didapatkan kesalahan rata-rata sebesar 2,94\%. Berdasarkan dari analisa diatas, secara keseluruhan alat ukur kekentalan oli SAE 10-30 dengan meggunakan metode FBV small tube dapat berfungsi dengan baik.

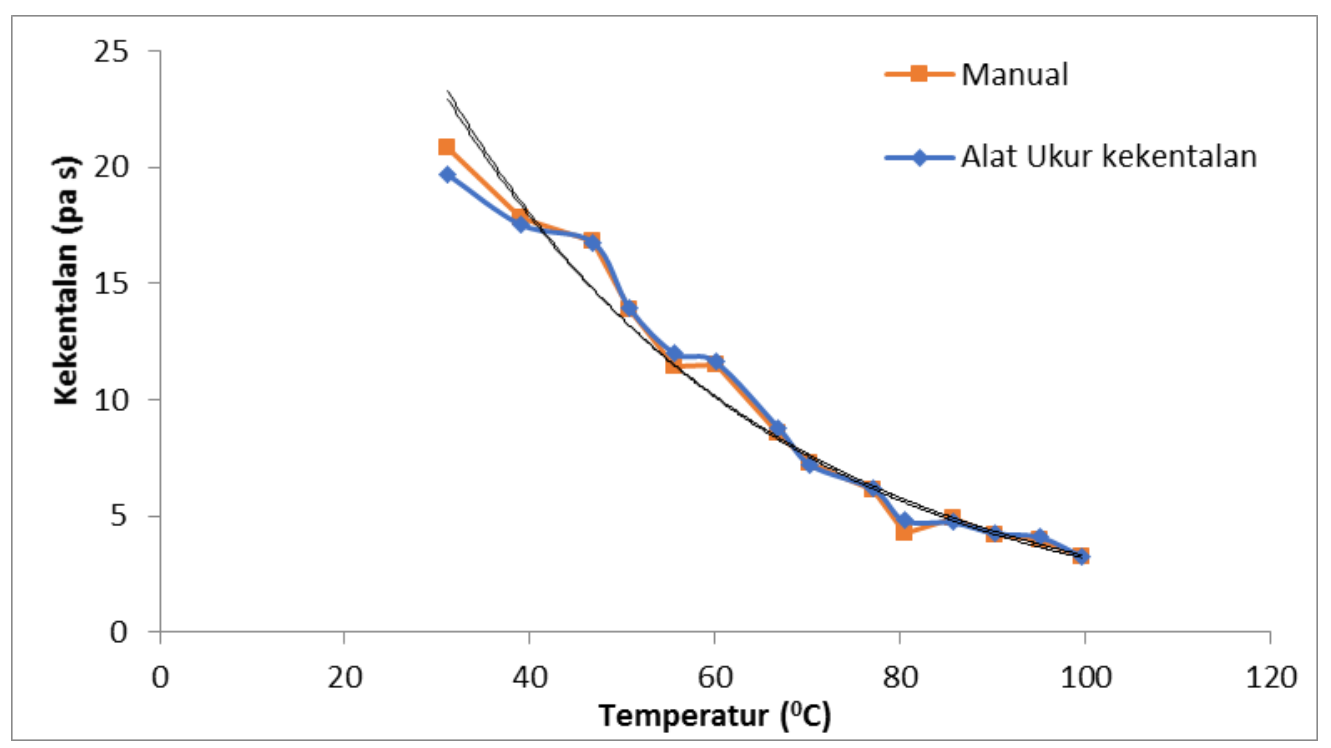

Gambar 6 Perbandingan data hasil pengujian alat ukur menggunakan metode FBV small tube dengan data acuan saat temperatur turun.

\section{KESIMPULAN}

Berdasarkan pengujian dan analisis yang telah dilakukan, maka dapat disimpulkan bahwa alat ukur keketalan oli SAE 10-30 menggunakan metode FBV small tube dapat digunakan untuk menentukan nilai kekentalan, hal ini dapat dilihat dari hasil pengukuran 
oli menggunakan alat ukur pada saat temperatur naik memiliki nilai regresi 0,991, dapat dilihat juga kesalahan rata-rata sebesar $1,17 \%$. Pengukuran oli menggunakan alat ukur ketika temperatur turun dengan nilai regresi 0,977, hasil perhitungan error didapatkan kesalahan rata-rata sebesar $2,94 \%$.

\section{DAFTAR PUSTAKA}

1. Estien, Y., 2005, Kimia Fisika untuk Paramedis, Andi, yogyakarta.

2. Fraden, J., 1996, The Hand Book of Modern Sensor, Thermoscan, Inc., California.

3. Kim, W. J., Kim, S., Huh, C., Kim, B. K., dan Kim, Y.J., 2016, A Novel Hand-Held Viscometer Applicable for Point-of-Care, Sensor and Actuator B, Elsevier, hal. 239246, Universitas Hansung, Korea Utara.

4. Sulhan. S. 2006, Mudah dan Menyenangkan Belajar Mikrokontroler, Yogyakarta.

5. Soedojo, P., 2004, Fisika Dasar, ANDI, Yogyakarta.

6. Tissos, N.P., Yulkifli dan Kamus, Y., 2014, Pembuatan Sistem Pengukuran Viskositas Fluida secara digital Menggunakan sensor Efek Hall UGN3505 Berbasis Arduino Uno328, Jurnal Sainstek Vol. VI No.1, Jurusan Fisika FMIPA Universitas Negeri Padang, hal 71-83. 